\title{
Effects of Tea-Seed Saponins on the Vase Life, Hydraulic Conductance and Transpiration of Cut Rose Flowers
}

\author{
Kazuo ICHIMURA ${ }^{1 *}$, Takahiro FUJIWARA ${ }^{2}$, Yuji YAMAUCHI ${ }^{3}$, \\ Hideki HORIE ${ }^{4}$ and Katsunori KOHATA ${ }^{5}$ \\ ${ }^{1}$ Department of Production, National Institute of Floricultural Science \\ (Tsukuba, Ibaraki 305-8519, Japan) \\ ${ }^{2}$ Department of Vegetable Science, National Agricultural Research Center for Western Region \\ (Ayabe, Kyoto 623-0035, Japan) \\ ${ }^{3}$ Graduate School of Pharmaceutical Science, Osaka University (Suita, Osaka 565-0871, Japan) \\ ${ }^{4}$ Department of Physiology and Quality Science, National Institute of Vegetable and Tea Science \\ (Ano, Mie 514-2392, Japan) \\ ${ }^{5}$ Department of Physiology and Quality Science, National Institute of Vegetable and Tea Science \\ (Kanaya, Shizuoka 428-8501, Japan)
}

\begin{abstract}
Saponin(s) was extracted from tea seeds, and its effect on the vase life, transpiration from leaves and hydraulic conductance of stem segments in cut roses (Rosa hybrida L. cv. Sonia) were investigated. The continuous treatment with tea-seed saponins (TSS) at $20 \mathrm{mg} \mathrm{L}^{-1}$ significantly extended the vase life of cut rose flowers, but those at other concentrations did not. The volume of water uptake and water loss by the cut flowers decreased with increasing concentration of TSS. TSS induced stomatal closure. In cut flowers kept in water, hydraulic conductance of the stem segment decreased with time, and $20 \mathrm{mg} \mathrm{L}^{-1}$ TSS treatment considerably suppressed this decrease. The results show that TSS markedly inhibited transpiration from leaves and suppressed decrease in hydraulic conductance, which may be responsible for a significant increase in vase life.
\end{abstract}

Discipline: Postharvest technology

Additional key words: cut flower, Rosa hybrida, water relations

\section{Introduction}

The vase life of cut rose flowers is often very short due to wilting and bending of the floral axis just below the flower head. The development of these symptoms is considered to be caused by vascular occlusion which inhibits water supply to the flowers ${ }^{1,12,23}$. The development of this occlusion is correlated with the growth of bacteria at the cut surface and inside the stem $^{27}$, and addition of bacteria to vase water shortens the vase life of cut rose flowers ${ }^{2,31}$. Thus, vascular occlusion has been considered to be partially due to bacteria. To inhibit bacterial proliferation, germicides, such as silver nitrate, aluminum sulfate and 8-hydroxyquinoline sulfate (HQS), have been used in commercial preservatives. ${ }^{5}$. These germicides inhibit vascular occlusion ${ }^{3,7,27}$ and extend the vase life of cut rose flowers ${ }^{3,7-9,14}$. In addition to germicides, pulse treatment with some surfactants, such as Agral-LN and Atlas G 2130, are also effective in extending the vase life of many cut flowers when the cut flowers had been exposed to air ${ }^{24}$. Surfactants may decrease surface tension, thereby facilitating entry of water into cut stems. Previously, Ueyama and Ichimura ${ }^{22}$ reported that pulse treatment with 2-hydroxy-3-ionene chloride polymer (HICP) extended the vase life of cut roses. This effect was suggested to be due to inhibition of transpiration from leaves and its surfactant action ${ }^{22}$.

Saponins are surface-active sterol or triterpene glycosides and found in a great variety of plants. Saponins prepared from various sources, such as tea leaves, have antimicrobial activity ${ }^{13,17}$. Tea seeds have a large amount of saponins, more than $10 \%$ of their dry weight ${ }^{29}$. A mixture of saponins prepared from tea seeds (TSS) inhibits growth of yeasts ${ }^{20,30}$. Addition of bacteria to vase water causes vascular occlusion ${ }^{16,26}$ and shortens the vase life of cut rose flowers ${ }^{16,31}$. Similarly, yeasts markedly shorten the vase life of cut rose, carnation and chrysanthemum ${ }^{31}$.

*Corresponding author: fax +81-29-83-6841; e-mail ichimu@affrc.go.jp

Received 15 September 2004; accepted 15 November 2004. 
Microbial proliferation causes vascular occlusion ${ }^{27}$, which has been evaluated by measuring the hydraulic conductance of the $\mathrm{stem}^{3,22,27}$. We thus, investigated effects of TSS on the vase life, transpiration and stem hydraulic conductance of cut rose flowers.

\section{Materials and methods}

\section{Preparation of saponins from tea seeds}

Seeds of tea (Camellia sinensis var. sinensis cv. Yabukita) were collected in the field of National Institute of Vegetable and Tea Science (Kanaya, Shizuoka). After removal of the pericarp, tea seeds were ground with mortar and pestle and dried in vacuo at $40^{\circ} \mathrm{C}$. The resulting powder was treated with n-hexane $(500 \mathrm{~mL} \times 2)$ to remove tea-seed oils, and then extracted with $80 \%$ methanol twice. The resulting extract was evaporated to dryness in vacuo below $40^{\circ} \mathrm{C}$. The residue was dissolved in $40 \%$ methanol and applied onto a column of Lobar Prepack column RP-18 (MERCK, $25 \mathrm{~mm} \times 31 \mathrm{~cm}$ ). The composition of the mobile phase was changed step by step from 40 to $100 \%$ methanol at a flow rate of $3.0 \mathrm{~mL}$ $\mathrm{min}^{-1}$ below $40^{\circ} \mathrm{C}$. The fractions containing TSS were collected by monitoring at $250 \mathrm{~nm}$ with a UV detector and evaporated to dryness below $40^{\circ} \mathrm{C}$ to yield a white solid.

\section{Plant material and TSS treatment}

Cut rose (Rosa hybrida L. cv. Sonia) flowers, which were obtained from a commercial grower (Ano, Mie Prefecture) at normal harvest maturity (sepals starting to reflex), were placed in tap water and used for experiments within $2 \mathrm{~h}$ after harvest. Flower stems were trimmed to $40 \mathrm{~cm}$, and all leaves except for the upper 3 to 5 leaflets were removed. In the control, cut flowers were treated with distilled water. Two flowers were transferred to a $500-\mathrm{mL}$ beaker containing $500 \mathrm{~mL}$ distilled water or various concentrations of TSS. The experimental conditions were temperature of $23^{\circ} \mathrm{C}, 70 \%$ relative humidity, and a 12-h photoperiod under $10 \mu \mathrm{mol} \mathrm{m} \mathrm{m}^{-2} \mathrm{~s}^{-1}$ irradiance from cool-white fluorescence lamps. Eight flowers were used for each treatment. Vase life was the period from the time of putting the stem into the test solution to the time when the petals lost turgor. The fresh weight of cut flowers and the volume of water uptake were measured daily. The volume of water loss was calculated by subtracting the increase in fresh weight from the volume of water uptake.

\section{Measurement of stomatal conductance from leaves}

Stomatal conductance of second leaves from the upper position was measured by a portable photosynthe- sis system (LI-6400, LICOR, Lincoln, NB, USA) according to the instruction manual. The environmental conditions were $23^{\circ} \mathrm{C}, 70 \%$ relative humidity and illumination under $10 \mu \mathrm{mol} \mathrm{m} \mathrm{m}^{-2} \mathrm{~s}^{-1}$ irradiance.

\section{Determination of stem hydraulic conductance}

Hydraulic conductance of the stem segment was measured by the method of Gilman and Steponkus ${ }^{3}$ with a slight modification. The basal $5 \mathrm{~cm}$ of the stem was inserted into a silicon tube (internal diameter $4 \mathrm{~mm}$ ), and a $130 \mathrm{~cm}$ head pressure of $10 \mathrm{mM} \mathrm{KCl}$ solution $(13 \mathrm{kPa})$ was applied $^{28}$. After $1 \mathrm{~h}$ of equilibration, the $\mathrm{KCl}$ solution that had passed through the segments was collected in attached tubes for $1 \mathrm{~h}$. The flow rate was determined by measuring the volume of the collected solution. In one experiment, two stem segments were used from one vessel, and each experiment was repeated three times.

\section{Results}

\section{Effect of TSS on the vase life of cut rose flowers}

TSS at $20 \mathrm{mg} \mathrm{L}^{-1}$ significantly extended the vase life of cut rose flowers (Table 1). TSS at other concentrations tended to extend vase life, but this effect was not significant at $\mathrm{P}<0.05$. TSS at $50 \mathrm{mg} \mathrm{L}^{-1}$ or higher concentrations caused visible damage to leaves of cut flowers. The rate of flower opening was not affected by TSS (data not shown).

\section{Changes in water uptake and water loss}

The volume of water uptake by the control flowers tended to increase during the first 5 days, decreased on day 6 and remained almost constant thereafter (Fig. 1A). Treatment with saponins suppressed the increase in solution uptake with increasing concentration of saponins. The changes in the rate of water loss were similar to those of water uptake (Fig. 1B).

Table 1. Effects of TSS concentration on the vase life of cut 'Sonia' roses

\begin{tabular}{cc}
\hline \hline $\begin{array}{c}\text { TSS concentration } \\
\left(\mathrm{mg} \mathrm{L}^{-1}\right)\end{array}$ & $\begin{array}{c}\text { Vase life } \\
(\text { day })\end{array}$ \\
\hline 0 & $7.0 \pm 0.3 \mathrm{a}$ \\
2 & $7.5 \pm 0.3 \mathrm{a}$ \\
5 & $7.4 \pm 0.2 \mathrm{a}$ \\
20 & $8.8 \pm 0.2 \mathrm{~b}$ \\
50 & $7.9 \pm 0.3 \mathrm{a}$ \\
\hline
\end{tabular}

Values represent mean of 4 replications \pm S.E., and those with the same letters are not significantly different $(\mathrm{P}<0.05)$ by the Tukey-Kramer's multiple range test. 

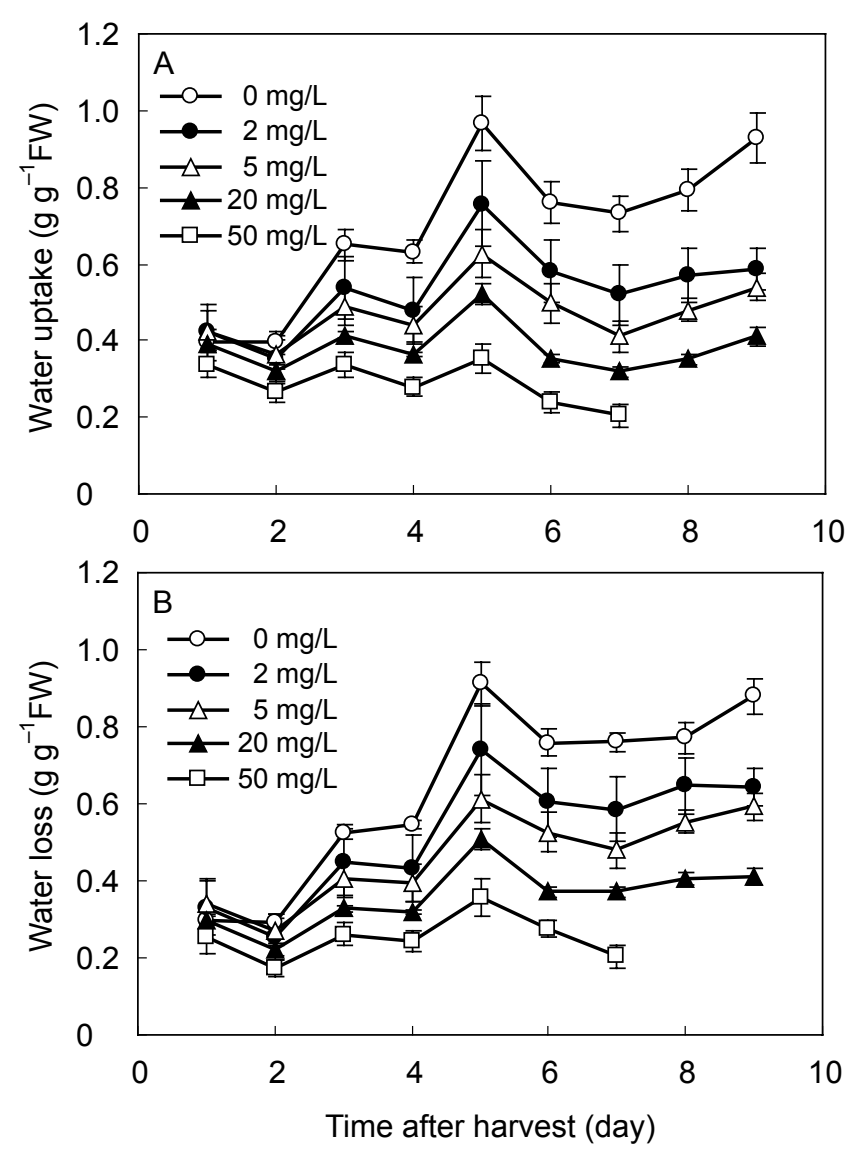

Fig. 1. Changes in water uptake (A) and loss (B) of cut 'Sonia' roses treated with TSS at various concentrations with time

Values are means of 3 replications \pm S.E.

\section{Stomatal conductance of leaves}

In the control flowers, the stomatal conductance in the leaves increased on the 1 st day and remained almost constant thereafter except that it tended to decrease on the 2nd day (Fig. 2). Treatment with TSS decreased the stomatal conductance of leaves on the 1 st day regardless of its concentration.

\section{Changes in stem hydraulic conductance}

In the control flowers, the hydraulic conductance of the stem segments slightly increased on the 1st day, and sharply decreased thereafter. Hydraulic conductance of those treated with TSS at $20 \mathrm{mg} \mathrm{L}^{-1}$ also increased on the 1st day, and decreased thereafter, but this decrease was considerably suppressed by TSS treatment during the later part of the vase life (Fig. 3).

\section{Discussion}

In the present study, we found that the transpiration from the cut flowers was decreased by TSS treatment

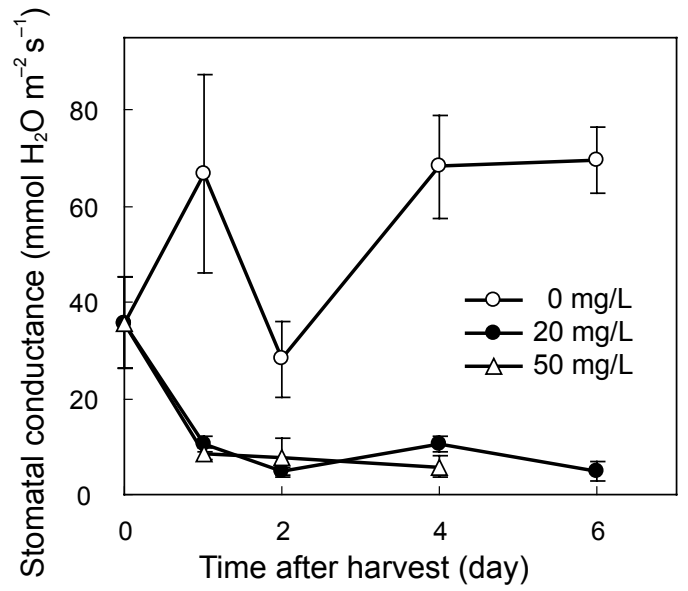

Fig. 2. Changes in stomatal conductance of cut 'Sonia' roses treated with TSS at various concentrations with time

Values are means of 9 replications \pm S.E.

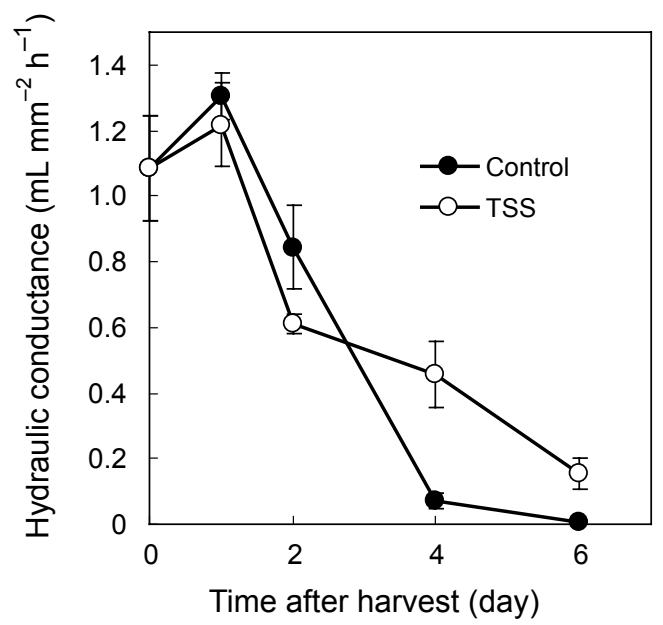

Fig. 3. Changes in hydraulic conductance of stem segments in cut 'Sonia' roses treated with $20 \mathrm{mg} \mathrm{L}^{-1}$ TSS with time

Values are means of 3 replications \pm S.E.

(Fig. 1B). This inhibition was shown to be due to the stomatal closure (Fig. 2). TSS of at least $2 \mathrm{mg} \mathrm{L}^{-1}$, a low concentration, suppressed transpiration from cut flowers (Fig. 1B). Saponins are major compounds in plants, but their physiological actions on plants have been little understood. To the best of our knowledge, this is the first evidence that demonstrated the suppression of transpiration from leaves by closing stomata with saponins. TSS is a mixture of structural analogues and geometrical isomers including theasaponin E1 and theasaponin E2 ${ }^{10}$. Yamauchi et al. ${ }^{30}$ reported that theasaponin E1, which is a major saponin in tea seeds, inhibited the proliferation of yeasts. However, it is yet to be investigated to understand what kind of compound(s) in TSS induces stomatal closure of leaves. 
In our study, a continuous treatment with TSS at 20 $\mathrm{mg} \mathrm{L}^{-1}$ significantly extended the vase life of cut rose flowers (Table 1). In the presence of vascular occlusion in the stem, a high rate of transpiration disrupts the water balance, which may then shorten the vase life of cut roses $^{23}$. Since excess transpiration from leaves disrupts water balance in cut roses, the extension of vase life by TSS may partially be attributed to inhibition of transpiration from leaves. Abscisic acid (ABA) also closes stomata, and inhibits transpiration from leaves ${ }^{11}$. Treatment with ABA extends the vase life of cut roses with leaves but ABA shortens the vase life of roses without leaves ${ }^{6}$.

The short vase life of cut rose flowers is considered to be due to disruption of water balance, which is mainly caused by vascular occlusion ${ }^{23}$. TSS considerably suppressed the decrease in hydraulic conductance of the stem segment (Fig. 3), suggesting that TSS inhibits development of vascular occlusion. Vascular occlusion has been considered to be mainly due to microbial proliferation ${ }^{23}$. The addition of yeasts to vase water markedly shortened the vase life of cut rose, carnation and chrysanthemum ${ }^{31}$. Saponins are known to have germicidal activity ${ }^{13,17}$ and TSS at a low concentration inhibited the proliferation of yeasts $^{20,30}$. However, whether TSS suppresses bacterial proliferation remains unknown. $\mathrm{Put}^{15}$ reported that yeasts proliferated in vase water in which cut roses were placed although van Doorn et al. ${ }^{25}$ reported with electronmicroscopic studies that yeasts were not observed in cut rose stems held in water. The effect of TSS on the vase life may be partially attributed to their inhibitory action against microbial growth. Several germicides, such as aluminum sulfate, silver nitrate and HQS, which are well known germicides, inhibit vascular occlusion and extend the vase life of cut roses $^{23}$. Although TSS suppressed decrease in hydraulic conductance in stem segments, hydraulic conductance on the 6th day was low. On the contrary, continuous treatment with HQS maintained hydraulic conductance in cut rose stems during the first 7 days $^{7}$. Thus, inhibition with TSS on development of vascular occlusion is not so large, compared to that of HQS.

Some surfactants, such as Agral-LN, have been reported to overcome vascular occlusion of cut flowers without inhibiting microbial growth ${ }^{23}$. These surfactants may decrease surface tension of water, thereby facilitating entry of water into cut stems ${ }^{23}$. $\mathrm{Uda}^{21}$ reported that some surfactants including polyoxyethylenelaurylether increased water uptake in cut stock flowers. Although saponins are natural surfactants, TSS did not increase water uptake of cut roses (Fig. 1A). Thus, the effect of TSS on the extension of vase life may not be attributed to surfactant action.

Continuous treatment with aluminum sulfate, which is widely used in preservative formulations as a germicide $^{4}$, extends the vase life of cut roses ${ }^{8}$. Since aluminum sulfate inhibits transpiration from leaves ${ }^{18,19}$, the effect of TSS on the vase life of cut roses is somewhat similar to that of aluminum sulfate. Similarly, the function of TSS may be comparable to that of a pulse treatment with HICP, which extends the vase life of cut rose. HICP was found to inhibit development of vascular occlusion and transpiration rate ${ }^{22}$ although whether HICP induces stomatal closure remains unclear. In the present study, the effect of TSS on the vase life of cut roses was not so appreciable. Furthermore, TSS at $50 \mathrm{mg} \mathrm{L}^{-1}$ or higher concentrations caused severe visible damage to the leaves. Thus, it appears that the treatment with TSS alone is not practically useful in extending the vase life of cut rose flowers. Further studies, therefore, will be needed to clarify whether combined treatment of TSS with some other compounds, such as sugars and germicides, is more effective in extending the vase life of cut roses.

In conclusion, continuous treatment with TSS at 20 $\mathrm{mg} \mathrm{L}^{-1}$ significantly extended the vase life of cut rose flowers. TSS inhibited the transpiration from leaves and suppressed decrease in hydraulic conductance of cut stems, which may be responsible for extension of vase life. It should be noted that TSS at a low concentration induced stomatal closure and inhibited transpiration from leaves of cut roses.

\section{Acknowledgments}

We thank Dr. U. K. Pun for his critical reading of this manuscript and Mrs. K. Matsuda for her helpful assistance.

\section{References}

1. de Stigter, H. C. M. (1980) Water balance of cut and intact Sonia rose plants. Z. Pflanzenphysiol., 99, 131140.

2. de Witte, Y. \& van Doorn, W. G. (1988) Identification of bacteria in the vase water of roses, and the effect of the isolated strains on water uptake. Sci. Hortic., 35, 285291.

3. Gilman, K. F. \& Steponkus, P. L. (1972) Vascular blockage in cut roses. J. Am. Soc. Hort. Sci., 97, 662-667.

4. Goszczynska, D. M. \& Rudnicki, R. M. (1988) Storage of cut flowers. Hort. Rev., 10, 35-62.

5. Halevy, A. H. \& Mayak, S. (1981) Senescence and postharvest physiology of cut flowers, part 2. Hort. Rev., 3, 59-143.

6. Halevy, A. H. et al. (1974) Opposing effects of abscisic acid on senescence of rose flowers. Plant Cell Physiol., 15, 813-821. 
7. Ichimura, K., Kojima, K. \& Goto, R. (1999) Effects of temperature, 8-hydroxyquinoline sulphate and sucrose on the vase life of cut rose flowers. Postharvest Biol. Technol., 15, 33-40.

8. Ichimura, K. \& Ueyama, S. (1998) Effects of temperature and application of aluminum sulfate on the postharvest life of cut rose flowers. Bull. Natl. Res. Inst. Veg., Ornam. Plants Tea, 13, 51-60.

9. Jones, R. B. \& Hill, M. (1993) The effect of germicides on the longevity of cut flowers. J. Am. Soc. Hort. Sci., 118, 350-354.

10. Kitagawa, I. (1992) Chemical investigation of naturally occurring drug materials. Elucidation of scientific basis for traditional medicines and exploitation of new naturally occurring drugs. Yakugaku Zasshi (J. Pharm. Soc. Jpn.), 112, 1-41 [In Japanese].

11. Mansfield, T. A. \& McAinsh, M. R. (1995) Hormones as regulators of water balance. In Plant hormones. ed. Davies, P. J., Kluwer Academic Publishers, Dordrecht, 598-616.

12. Mayak, S. et al. (1974) The water balance of cut rose flowers. Physiol. Plant., 31, 15-22.

13. Murakami, F. (1996) Antimicrobe of yucca saponin and its utilization. Food Process, 31, 13-16 [In Japanese].

14. Ohkawa, K., Kasahara, Y. \& Suh, J. -N. (1999) Mobility and effects on vase life of silver-containing compounds in cut rose flowers. HortScience, 34, 112-113.

15. Put, H. M. C. (1990) Micro-organisms from freshly harvested cut flower stems and developing during the vase life of chrysanthemum, gerbera and rose cultivars. Sci. Hortic., 43, 129-144.

16. Put, H. M. C. \& Jansen, L. (1989) The effects on the vase life of cut Rosa cultivar 'Sonia' of bacteria added to the vase water. Sci. Hortic., 39, 167-179.

17. Sagesaka, Y. M. et al. (1996) Antimicrobial and antiinflammatory actions of tea-leaf saponin. Yakugaku Zasshi (J. Pharm. Soc. Jpn.), 116, 238-243 [In Japanese].

18. Schnabl, H. (1976) Der Einflu von Aluminiumionen auf den Starkemetabolismus von Vicia faba-Epidermen. $Z$. Pflanzenphysiol., 77, 167-173 [In German].

19. Schnabl, H. \& Ziegler, H. (1975) Über die Wirkung von
Aluminiumionen auf die Stomatabewegung von Vicia faba-Epidermen. Z. Pflanzenphysiol., 74, 394-403 [In German].

20. Tomita, M. et al. (2000) Theasaponin E1 destroys the salt tolerance of yeasts. J. Biosci. Bioeng., 90, 637-642.

21. Uda, A. (1990) Extension of the vase life of cut flowers. $\mathrm{V}$. Effect of surfactant pretreatment on water uptake of cut stocks (Matthiola incana R. Br.). Bull. Hyogo Pre. Agri. Inst., 38, 59-64 [In Japanese].

22. Ueyama, S. \& Ichimura, K. (1998) Effects of 2-hydroxy3 -ionene chloride polymer on the vase life of cut rose flowers. Postharvest Biol. Technol., 14, 65-70.

23. van Doorn, W. G. (1997) Water relations of cut flowers. Hort. Rev., 18, 1-85.

24. van Doorn, W. G., Abadie, P. \& Belde, P. J. M. (2002) Alkylethoxylate surfactants for rehydration of roses and Bouvardia flowers. Postharvest Biol. Technol., 24, 327333.

25. van Doorn, W. G. et al. (1991) Micro-organisms at the cut surface and in xylem vessels of rose stems: a scanning electron microscope study. J. Appl. Bacteriol., 70, 3439.

26. van Doorn, W. G. \& de Witte, Y. (1991) Effect of bacterial suspensions on vascular occlusion in stems of cut rose flower. J. Appl. Bacteriol., 71, 119-123.

27. van Doorn, W. G., Schurer, K. \& de Witte, Y. (1989) Role of endogenous bacteria in vascular blockage of cut rose flowers. J. Plant Physiol., 134, 375-381.

28. van Ieperen, W., van Meeteren, U. \& van Gelder, H. (2000) Fluid ionic composition influences hydraulic conductance of xylem conduits. J. Exp. Bot., 51, 769-776.

29. Xingtu, F. (1990) Main chemical compounds and their content changes in tea fruit as its ripening. J. Tea Sci., 10, 49-58.

30. Yamauchi, Y. et al. (2001) Development of a simple preparation method for tea-seed saponins and investigation on their antiyeast activity. $J A R Q, \mathbf{3 5}, 185-188$.

31. Zagory, D. \& Reid, M. S. (1986) Role of vase solution microorganisms in the life of cut flowers. J. Am. Soc. Hort. Sci., 111, 154-158. 